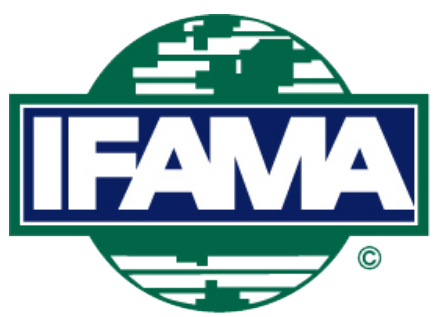

International Food and Agribusiness Management Review

Volume 25, Issue 2, 2022; DOI: 10.22434/IFAMR2021.0088

Received: 15 July 2021 / Accepted: 24 October 2021

\title{
Relationship between brand and dealer loyalty in the agricultural equipment market
}

\section{RESEARCH ARTICLE}

\author{
Roberto Feeney ${ }^{\oplus a}$, Pedro Harmath ${ }^{\mathrm{b}}$, Josefa Ramoni-Perazzic $^{\mathrm{c}}$ and Pablo Mac Clay ${ }^{\mathrm{d}}$ \\ ${ }^{a}$ Associate Professor, ${ }^{d}$ Assistant Professor, Center for Food \& Agribusiness, Austral University, \\ 1950 Paraguay Street, Rosario city, Santa Fe Province 2000, Argentina \\ ${ }^{b}$ Associate Professor, Department of Mathematics, Austral University, \\ 1950 Paraguay Street, Rosario city, Santa Fe Province 2000, Argentina
}

${ }^{c}$ Full Professor, Escuela de Economía y Administración, Universidad Industrial de Santander, carrera 27, calle 9, Ciudad Universitaria. Bucaramanga city, Santander Province, Colombia

\begin{abstract}
Agricultural equipment companies intend to understand agriculture producers' buying behavior by answering questions such as how loyal producers are to brands and dealers, which have an important impact on their profitability. This paper addresses the problem of how loyal agricultural producers are to equipment brands and dealers. Using a combination of cluster analysis and probit models, we identified producers' behavioral and attitudinal loyalty to brands and dealers and analyzed the factors that explain such loyalty. We also found a strong interdependence between brand and dealer loyalty and the significant value that dealer loyalty adds to the brands. Additionally, we present some management implications of developing brand recognition, understanding producers purchasing behavior, and segmenting producers. This paper's contributions are the establishment and measurement of an 'empirical' definition of brand and dealer loyalty, the identification and quantification of the impact of the explanatory factors of brand and dealer loyalty, and the determination of a dual loyalty relationship between brand and dealer loyalty.
\end{abstract}

Keywords: ag equipment firms and dealers, agricultural producers, brand loyalty, dealer loyalty, probit models JEL code: C25, C35, Q12, Q13

(1)Corresponding author: rfeeney@austral.edu.ar 


\section{Introduction}

Agricultural equipment is more expensive than other inputs and plays a strategic role in the agricultural production function. Its importance relies not only on financial aspects but also on the end-product itself, and the continuation of the production process (Möller and Laaksonen, 1986). When producers start planning the purchase of capital equipment, the decision-making process is deeply reasoned; social and emotional factors are involved, and the number of sources of information and alternatives to evaluate the equipment tend to multiply (Kool et al., 1997).

To properly perform their tasks at sowing, spraying, and harvesting, important times for any crop, producers do not only need the equipment, but also the services, the technical support, the supply of spare parts, and financial assistance. Dealers provide most of these services. Industry reports show that dealership plays a critical role in achieving customer loyalty to the agricultural capital equipment brands sold in the market (Ag Equipment Intelligence, 2018), and customer loyalty is crucial for companies' profitability (Fortes et al., 2019).

Thus, this raises questions regarding which loyalties prevail in the agricultural capital equipment markets: loyalty to the brands or loyalty to the dealers? How loyal are agricultural producers to brands and dealers? Which are the factors that explain brand and dealer loyalty, and which are the interactions between brand and dealer loyalty?

Understanding the relationship between brand and dealer loyalty for ag capital equipment is a relevant issue in the agribusiness context due to: (a) the increasing importance of B2B branding to improve firms' competitive performance in industrial markets (Cassia and Magno, 2019); (b) the role of B2B branding in the purchasers' decision-making process (Nyström et al., 2018; Walley et al., 2007); (c) additionally, the global market of agricultural capital equipment is huge, with revenues of around 200 billion US dollars a year, expected to reach 244 billion US dollars by 2025 (Reportlinker, 2019).

Therefore, this paper addresses the problem of how loyal agricultural producers are to equipment brands and dealers, as well as defining the factors that influence both types of loyalty. In particular, we focus on the following questions:

- How loyal are Argentinian producers, in the Humid Pampas, to agricultural capital equipment brands and dealers?

- Which are the factors that impact brand and dealer loyalty?

- Are brand loyalty and dealer loyalty associated and do they influence each other?

Being relevant questions for capital equipment suppliers, there is very limited research done in the area. The novelty of this paper lies in setting an 'empirical' definition of brand and dealer loyalty and measuring it, identifying its explanatory factors, and determining a dual relationship between brand and dealer loyalty. This paper follows with the literature review, methods, results, discussion, and conclusions.

\section{Literature review}

Agricultural equipment markets are considered to be industrial markets with specific characteristics: few and large transactions, several people involved in every purchase, strongly informed and rational buyers, close buyer-seller relationship, extended negotiations, need for customization, scarce buying frequency, and importance of second-hand markets. Any transaction in these markets is a major equipment purchase and entails great economic and financial risks (Harbor, 2006; Viardot, 2017; Walley et al., 2007).

Agricultural producers act as business customers when interacting with capital equipment suppliers, similar to what can be observed in a non-farm business-to-business (B2B) environment (Harbor, 2006). B2B relationships include interactions between manufacturers, wholesalers, and retailers, as well as between 
agribusiness firms and agricultural producers (Lilien, 2016). Purchasers in the B2B markets tend to be professional, rational, and expert buyers. However, previous research has established the importance of psychological and emotional factors in the process of buying industrial products and services (Elsäßer and Wirtz, 2017; Leek and Christodoulides, 2012; Steward et al., 2019).

Industrial purchasers are not insensitive to brands, especially in complex buying situations in which branding has the largest impact (Brown et al., 2007; Hutton, 1997). The more complex the purchasing situation, the higher the perceived risk, and the more the B2B purchaser will tend to select well-known brands (Leek and Christodoulides, 2012; Mudambi, 2002).

Brand loyalty is a multidimensional concept consisting of a mix of both behavioral and attitudinal dimensions that benefits one firm relative to its competitors (Watson et al., 2015). Behavioral loyalty is understood as the customer's intention and action of repurchasing the same product over time, or the repetitive purchases that result in the extension of the purchases and expenditures with the same provider (Dick and Basu 1994; Gupta et al., 2017; Rundle-Thiele and Bennett, 2001; Tabaku and Zerellari, 2015).

Attitudinal loyalty consists of a deeply held commitment to a firm or brand, and on the consumers' intention to buy it consistently in the future (Bourdeau, 2005; Maseshwari et al., 2014; Oliver, 1999). It is a psychological process that makes a brand preferable over others (Jones and Taylor, 2007; Oliver, 1999). Researchers have conceptualized attitudinal loyalty as a customer predisposition towards brands, in terms of preference, intention to repurchase, and commitment (Rundle-Thiele, 2005).

The combination of behavioral and attitudinal loyalty is a more valid and reliable method to measure customer loyalty because neither behavioral loyalty nor attitudinal loyalty alone can systematically evaluate and analyze the construct of brand loyalty (Jones and Taylor, 2007; Oliver, 1999; Tabaku and Zerellari, 2015).

Previous research on branding for B2B markets has extensively established the benefits of strong brands for industrial firms (Cassia and Magno, 2019; Cassia et al., 2017; Kotler, 2000; Nyström, et al., 2018; Seyedghorban et al., 2016; Viardot, 2017; Walley et al., 2007). Hyper-competition, globalization, increasing product homogeneity, and the pressure of high prices have led to the implementation of B2B branding strategies in industrial markets (Seyedghorban et al., 2016). B2B branding business and economic principles should hold for agricultural producers' purchases of capital equipment (Harbor, 2006; Kool et al., 1997; Walley et al., 2007) as agricultural machinery is bought only sporadically and involves a large sum of money (Kool, 1994).

Agricultural producers rely on the vendors they trust when looking for alternatives to purchase capital equipment. Farmers tend to repeat brands if their previous experience was good, and thereby avoid searching for additional information or alternatives. Producers with a personal, sound relationship with a vendor do not search for more information and alternatives (Harbor, 2006; Kool et al., 1997; Walley et al., 2007).

Dealers are important partners to capital equipment manufacturers as they sell new products, deliver parts fast and service the machinery in the event there is an equipment failure or collapse (Walley et al., 2007). Manufacturers' brands are an important factor in the dealership's performance, as the value of a brand name can attract customers, increase demand, income, and profits. At the same time, the dealer is where the customer meets the product. Furthermore, better product and service quality lead to deeper customer satisfaction that, in turn, builds dealer loyalty, and greater brand loyalty (Anisimova and Mavondo, 2014; Glynn, 2010; Huber and Herrmann, 2001).

Mudambi (2002) developed a model of B2B branding based on the assumption that branding offers functional, emotional, and self-expression benefits to the business buyer. Well-known brands have the emotional benefit of reducing perceived risk and uncertainty, reinforce prior experiences and relationships, and build confidence in the professional buyer while, at the same time, increase customer satisfaction. 
Based on the literature of branding for B2B markets, Harbor (2006) developed a conceptual model that explains agricultural producers' loyalty to brands, and the relationship between brand loyalty and dealer loyalty in the US. The author evaluated the degree of dual loyalty (brand and dealer) for ag capital equipment and the influence of each type of loyalty on the other. Harbor concluded that activities that associate the dealer with the brand are likely to be helpful for building dual loyalty (loyalty to brands and dealers) in the agricultural equipment market. Harbor et al. (2008) highlight that the demographic variables are not the strongest indicators of brand loyalty in agribusiness, and that the most important indicators of loyalty are those related to the input purchasing process: such as attitudes, beliefs, and activities of the agricultural producers.

The literature review of previous studies on the topic provides us with a basis to select the independent variables of brand and dealer loyalty. However, so far, the literature exploring B2B loyalty in the context of agricultural capital equipment is scarce. As Habor et al. (2008) emphasize, little research specific to business-to-business relationships has been developed in the agricultural input markets literature recently.

\section{Materials and methods}

Our research methodology is mainly a statistical-quantitative approach. We start by collecting data and selecting the independent variables. Then, we identify loyal/disloyal producers with cluster analysis and test the impact of the variables on brand/dealer loyalty through biprobit models.

\subsection{Materials and data collection}

The main source of information for this paper was the survey called 'The needs of the Argentine agricultural producer 2017', conducted during June and July 2017, on a total of 818 agricultural producers. The survey aimed at analyzing farmers' purchasing behavior and understanding their underlying preferences when making decisions. The surveyed producers farm in the Humid Pampas, the main agricultural region in the country, and one of the major farming production areas in the world (Bedano and Domínguez, 2016; Korsakov et al., 2015; Montes de Oca et al., 2020).

This study defines agricultural producers as physical or legal persons growing soybeans, wheat, corn, and other grains on owned and/or rented land. To be included in the survey, farmers were required to have a farming operation equivalent to more than 300 hectares. Furthermore, the head of the farm, or the largest plot of land operated, should be located in the districts included in the sample (Mohammadi et al., 2020).

The questionnaire consisted of 58 questions, with two open-ended and 56 close-ended questions. The information was collected through personal interviews which took approximately one hour. Almost 852 agricultural producers were contacted, and 818 answered the entire questionnaire. Questions number 40 and 41 in the survey ask producers about their loyalty to the brands and dealers of the agricultural equipment they purchase. Based on the loyalty ladder framework (Narayandas, 2005), these questions intend to evaluate the extent to which producers consider themselves more or less loyal to such brands and dealers. Respondents were requested to agree or not with the following statements about the brands/dealers they primarily purchased (it was possible to select more than one option):

a. I will do more business with this brand/dealer.

b. I endorse this brand/dealer to my neighbors.

c. I try products from other brands/dealers.

d. I would switch to another brand/dealer to save $5 \%$.

e. I would switch to another brand/dealer to save $10 \%$.

f. I am loyal to this brand/dealer (I do not change brands/dealers even if prices increase more than 10\%).

To interpret the results, options c, d, and e are considered responses associated with disloyalty, since they show a disposition to switch brands (even when this switching may not happen in practice). On the other hand, options $\mathrm{a}, \mathrm{b}$, and $\mathrm{f}$ are considered replies associated with loyalty, since they imply that the producer is 
somehow involved with the brand (he would not switch even with higher prices, recommend it to neighbors, or seek to do more business with it). Although the initial sample included 818 individuals, inconsistencies in the responses led us to reduce the sample to 564 individuals, which remains statistically large.

In this research 'loyalty to brands' and 'loyalty to dealers' are regarded as dependent variables. Based on the literature, we selected the independent variables that influence both types of loyalty. The literature suggests that certain demographic characteristics of the producer such as their age, education, and income, as well as other characteristics related to the nature of the firm such as farm size, can exert an influence on both types of loyalty. On the other hand, it is to be expected that price, performance, the valuation of possible differences between products, and preferences towards different means of communication that producers use to acquire capital equipment, could play an important role in determining brand loyalty. While characteristics typical of the supplier, such as the financing granted to the producer, look like possible determinants of dealer loyalty. We also included in our research variables that we think are relevant in the Argentine context, and which have been acknowledged by the literature: the distance that exists between the place where the producer often lives and his farm, the percentage of rented land, and producers' cognitive styles (in terms of being analytical, intuitive, or balanced). See the list of independent variables in Supplementary Table S1.

\subsection{Methods}

We resort to cluster analysis to divide producers into segments based on their loyalty: this will allow identifying 'loyal' and 'disloyal' individuals. Second, we use a biprobit model to identify and quantify the impact of the independent variables on the two types of loyalty. Additionally, we use a seemingly unrelated regressions model to quantify the influence of one of the loyalty variables on the other in terms of interdependence.

\section{- Cluster analysis}

We apply cluster analysis to identify groups of producers based on their loyalty to capital equipment brands and dealers using the options available in questions 40 and 41 , respectively. The cluster analysis gives us the dependent or response variables that we will use to make our estimations under probit models. We use a hierarchical clustering agglomeration method called linkage by averages between groups, proposed by Sokal and Michener (1958). We calculate the similarities between the individuals in the sample by means of the binary Euclidean distance since the variables selected to carry out the cluster analyzes are all qualitative, each one with two response categories, which coding is 0 : no and 1: yes.

\section{- Univariate probit models and seemingly unrelated bivariate probit models}

The loyalty variables constructed through cluster analysis are either of the underlying or latent type, meaning that they are incompletely observed. Thus, these variables will be introduced into binary results models as an index of an unobserved propensity of the event under study (loyalty). Hence, in the results section below we refer to 'extended or empirical loyalty', for the brand and the dealer.

The univariate probit models assume that the model we want to estimate is given by:

$$
Y_{i}^{*}=X_{i} \beta_{i}+\varepsilon_{i}
$$

Where the indicator variable is:

$$
Y_{i}= \begin{cases}1 & \text { if } Y_{i}^{*}>0 \\ 0, & \text { otherwise }\end{cases}
$$

If $i=1$, Equation 2 represents whether the producer is loyal to the brand or not. The left side of Equation 1 is the underlying variable that represents its loyalty, based on a wider definition, that is, the higher the value 
of the indicator variable, the greater the probability that the producer is loyal, given the empirical evidence. The same analysis applies to the dealer, also based on a wider definition, such that $i=2$.

Given the assumption of normality for the terms of random disturbance or random error $\varepsilon_{i}$, the probability that $Y_{i}^{*}$ is less than or equal to $Y_{i}$ can be calculated as:

$$
P_{i}=P\left(Y_{i}=1 \mid X\right)=P\left(Y_{i}^{*} \leq Y_{i}\right)=P\left(Z_{i} \leq X_{i} \beta_{i}\right)=F\left(X_{i} \beta_{i}\right)
$$

where $P_{i}=P\left(Y_{i}=1 \mid X_{i}\right)$ expresses the probability of an event to happen, given the value(s) of $X_{i}$, or the explanatory variable(s), with $Z \sim N\left(0, \sigma^{2}\right)$, and $F$ as the standard normal cumulative distribution function.

This study also considers the application of seemingly unrelated bivariate probit models, used when two equations are estimated and the dependent variable on one of them is an explanatory variable in the other, just to see the influence of one kind of loyalty over the other (Seyoum, 2018). In our case, we can write the following equations:

$$
\begin{aligned}
& Y_{1}^{*}=X_{1} \beta_{1}+\varepsilon_{1} \\
& Y_{2}^{*}=\gamma Y_{1}+X_{2} \beta_{2}+\varepsilon_{2}
\end{aligned}
$$

where $\varepsilon_{1}$ and $\varepsilon_{2}$ have a normal joint distribution with zero means, variances of one, and a correlation of $\rho$. Thus, under the notation followed in Equations 4 and 5, in the latter equation the 'extended loyalty to the brands' enters as an independent variable. While in a second stage (changing the subscripts in the equations) the one that enters as an independent variable is the 'extended loyalty to dealers', regardless of which of the two is shown first as an explanatory variable (Gujarati, 2003; Seyoum, 2018).

\section{Results}

It is worth noting that all the results discussed in Section 4.1, 4.2 and 4.3 were obtained by making use of the Software Package for Social Sciences (SPSS) version 15.0 (IBM, Armonk, NY, USA), while the estimations for the probit analysis in Section 4.4 and 4.5 were obtained with the Statistical Package Stata 14 (StataCorp LLC, College Station, TX, USA).

\subsection{Descriptive statistics}

Some interesting findings emerge from the descriptive data presented in Table 1. Producers tend to be highly loyal to the brand/dealer even if prices increase up to 5 or $10 \%$. Few individuals stated that they would switch to other brands/dealers. However, if prices increase more than $10 \%$ (option $\mathrm{f}$ ), brand loyalty falls significantly, with only $33 \%$ of producers remaining loyal to brands and $27 \%$ to dealers.

\subsection{Cluster analysis}

Based on the loyalty variables shown in the table above, we perform a cluster analysis to segment producers according to their loyalty. In Table 2 we observe a first group of 182 producers who will continue doing business with the brand and show a strong commitment to it. Additionally, $85 \%$ of them claim that they would stick to the brand even when facing a price increase above $10 \%$.

This group of producers can be considered 'empirically loyal' to capital equipment brands. On the other hand, a second group includes 382 producers, which are 'empirically disloyal' to capital equipment brands. 
Table 1. Descriptive statistics for brand and dealer loyalty with $n=564$.

\begin{tabular}{|c|c|c|}
\hline \multirow[t]{2}{*}{ Characteristic } & \multirow{2}{*}{$\begin{array}{l}\text { Brands } \\
\text { Observed value } \\
(\%)\end{array}$} & \multirow{2}{*}{$\begin{array}{l}\text { Dealers } \\
\begin{array}{l}\text { Observed value } \\
(\%)\end{array} \\
\end{array}$} \\
\hline & & \\
\hline a. I will do more business with this brand/dealer & 73 & 74 \\
\hline b. I endorse this brand/dealer to my neighbors & 40 & 47 \\
\hline c. I try different brands/dealers of this product & 51 & 43 \\
\hline d. I would switch to another brand/dealer for $5 \%$ savings & 14 & 12 \\
\hline e. I would switch to another brand/dealer for $10 \%$ savings & 41 & 34 \\
\hline $\begin{array}{l}\text { f. I am loyal to this brand/dealer (I would not change brand/dealer even if the } \\
\text { price increases } 10 \% \text { ) }\end{array}$ & 33 & 27 \\
\hline
\end{tabular}

Table 2. Cluster solution for capital equipment brand loyalty with two groups. ${ }^{1,2}$

\begin{tabular}{|c|c|c|c|c|c|}
\hline \multirow[t]{3}{*}{ Characteristic } & \multirow{2}{*}{$\begin{array}{l}\text { Total } \\
\mathrm{n}=564\end{array}$} & \multirow{2}{*}{$\begin{array}{l}\text { Cluster } 1 \\
\mathrm{n}=182\end{array}$} & \multicolumn{3}{|l|}{ Cluster 2} \\
\hline & & & $\mathrm{n}=\mathbf{3 8 2}$ & $t$-test & \\
\hline & $\%$ of response & $\begin{array}{l}\% \text { of } \\
\text { response }\end{array}$ & $\begin{array}{l}\% \text { of } \\
\text { response }\end{array}$ & & \\
\hline I will do more business with this brand & $73 \%$ & $68 \%$ & $76 \%$ & 2.09 & $* *$ \\
\hline I recommend this brand to other farmers & $40 \%$ & $70 \%$ & $26 \%$ & -10.81 & $* * *$ \\
\hline $\begin{array}{l}\text { DID NOT SELECT I try different brands of this } \\
\text { product }\end{array}$ & $49 \%(100-51 \%)$ & $100 \%$ & $24 \%(100-76 \%)$ & 34.66 & $* * *$ \\
\hline $\begin{array}{l}\text { DID NOT SELECT I would change brand if the price } \\
\text { increases } 5 \%\end{array}$ & $86 \%(100-14 \%)$ & $100 \%$ & $79 \%(100-21 \%)$ & 10.13 & $* * *$ \\
\hline $\begin{array}{l}\text { DID NOT SELECT I would change brand if the price } \\
\text { increases } 10 \%\end{array}$ & $59 \%(100-41 \%)$ & $100 \%$ & $39 \%(100-61 \%)$ & 24.54 & $* * *$ \\
\hline $\begin{array}{l}\text { I am loyal to this brand (I would not change brand if } \\
\text { the price increases } 10 \% \text { ) }\end{array}$ & $33 \%$ & $85 \%$ & $8 \%$ & -25.29 & $* * *$ \\
\hline
\end{tabular}

With respect to dealer loyalty, as we see in Table 3, the first cluster is a group of 299 producers, whom we call 'empirically loyal' to the dealer. In the second cluster, there is a different group of producers, whom we call the 'empirically disloyal'.

In both cluster solutions, we may see that the $t$-tests for percentage comparison (assuming that the population variances are different) indicate that the differences for each variable between the groups are statistically significant. Therefore, we can conclude that there are two significantly different groups in terms of brand loyalty and dealer loyalty, as defined by the combination of six proposed variables. Furthermore, we can also conclude that the cluster solutions are statistically valid.

The cluster analysis results in a new concept of loyalty which considers a mix of behavioral/attitudinal variables to define brand/dealer loyalty. We will call this new loyalty 'extended or empirical loyalty'. We have found that $32 \%(182 / 564)$ of the producers in the sample can be considered 'empirically loyal' to brands of agricultural equipment, while 53\% (299/564) of them can be considered 'empirically loyal' to dealers. 
Table 3. Cluster solution for capital equipment dealer loyalty with two groups. ${ }^{1,2}$

\begin{tabular}{|c|c|c|c|c|c|}
\hline \multirow[t]{3}{*}{ Characteristic } & \multirow{2}{*}{$\begin{array}{l}\text { Total } \\
\mathrm{n}=564\end{array}$} & \multirow{2}{*}{$\begin{array}{l}\text { Cluster } 1 \\
\mathrm{n}=\mathbf{2 9 9}\end{array}$} & \multicolumn{3}{|l|}{ Cluster 2} \\
\hline & & & $n=265$ & $t$-test & \\
\hline & $\%$ of response & $\%$ of response & $\%$ of response & & \\
\hline I will do more business with this dealer & $74 \%$ & $78 \%$ & $69 \%$ & -2.38 & $* *$ \\
\hline I recommend this dealer to other farmers & $47 \%$ & $63 \%$ & $28 \%$ & -8.87 & $* * *$ \\
\hline $\begin{array}{l}\text { DID NOT SELECT I try different dealers of this } \\
\text { product }\end{array}$ & $57 \%(100-43 \%)$ & $97 \%(100-3 \%)$ & $13 \%(100-87 \%)$ & 35.82 & $* * *$ \\
\hline $\begin{array}{l}\text { DID NOT SELECT I would change dealer if the } \\
\text { price increases } 5 \%\end{array}$ & $88 \%(100-12 \%)$ & $98 \%(100-2 \%)$ & $77 \%(100-23 \%)$ & 7.64 & $* * *$ \\
\hline $\begin{array}{l}\text { DID NOT SELECT I would change dealer if the } \\
\text { price increases } 10 \%\end{array}$ & $66 \%(1-34 \%)$ & $83 \%(100-17 \%)$ & $48 \%(100-52 \%)$ & 9.29 & $* * *$ \\
\hline $\begin{array}{l}\text { I am loyal to this dealer (I would not change } \\
\text { dealer if the price increases } 10 \% \text { ) }\end{array}$ & $27 \%$ & $48 \%$ & $3 \%$ & -14.43 & $* * *$ \\
\hline
\end{tabular}

\subsection{Chi-square tests of association}

Now we present the relationship between the loyalty variables built above and each explanatory variable defined in our conceptual model, using the chi-square tests presented in Table 4.

For every variable, we can reject the null hypothesis of independence with brand loyalty, except for price and gross sales. In the case of dealer loyalty, the loyalty-unrelated variables are education, farm size, and how producers appreciate their relationship with the dealer. Thus, ten variables are related to brand loyalty, and five to dealer loyalty.

Table 4. Chi-square test between the dependents and each independent variable. ${ }^{1}$

\begin{tabular}{|c|c|c|c|}
\hline Variable & Name of the variable & $\begin{array}{l}\text { BLOYALTY: } \\
\text { loyalty to brands }\end{array}$ & $\begin{array}{l}\text { DLOYALTY: } \\
\text { loyalty to dealers }\end{array}$ \\
\hline EDUC & Education level of the farmer & $3.936^{* *}$ & 1.963 \\
\hline AGE & Age group of the farmer & $59.016^{* * *}$ & $17.384 * * *$ \\
\hline RESID & Residence (distance to farm) & $2.942 *$ & $2.702 *$ \\
\hline FSIZE & Farm size & $9.304 * * *$ & 2.997 \\
\hline PRL & $\%$ of rented land & $16.212 * * *$ & $18.869^{* * *}$ \\
\hline GS & Gross sales (US\$) & 4.078 & $8.609 * *$ \\
\hline $\mathrm{CS}$ & Cognitive style & $23.512 * * *$ & \\
\hline DBEBP & Differences between expendable and branded products & $52.026 * * *$ & \\
\hline PRICE & Appreciation of the attribute: price & 1.343 & \\
\hline PERFORM & Appreciation of the attribute: performance & $7.882 * * *$ & \\
\hline MEDSOU & Media source more frequented & $9.697 * * *$ & \\
\hline MEANVAL & Index measuring reported media exposure ranging from 1 to 6 & $\mathrm{tc}=3.414 * * *$ & \\
\hline FPDR & Financing provided by dealer/retailer & & $6.163^{* *}$ \\
\hline REL & $\begin{array}{l}\text { Appreciation of the attribute: relationship with dealer/ } \\
\text { concessionaire }\end{array}$ & & 1.341 \\
\hline
\end{tabular}


It is also of interest to analyze the relationship between the two different loyalties in the context of capital equipment, brand and dealer loyalty, as we can see in Table 5. The result for the chi-square statistic shows that, at any level of confidence, the constructed variables of brand loyalty and loyalty towards the dealer are not independent. The table clearly shows that producers who tend to be loyal to brands also tend to be loyal to dealers, and the same analysis naturally applies to those producers who tend to be disloyal.

\subsection{Univariate probit models}

To empirically determine the explanatory variables that influence brand loyalty and the ones that affect dealer loyalty we perform a univariate probit regression, whose results are presented in Supplementary Table S4. We especially consider models 1.4 and 2.3, because both contain only the 'surviving' variables that consistently proved to be statistically significant.

We come to realize that the factors that determine brand loyalty in the Argentinian agricultural equipment market are (with the corresponding sign of the relationship): education (-), age (-), cognitive styles $(+)$, perceived differences between expendable and branded products $(+)$, and performance $(+)$. On the other hand, the factors that influence dealer loyalty are age (-), residence $(-)$, percentage of rented land $(+)$, and gross sales $(+)$.

\subsection{Seemingly unrelated bivariate probit models}

The chi-square tests mentioned above determined that both types of loyalty are associated with each other at any significance level. We proceed to estimate a first bivariate probit model to analyze the influence and possible 'causality' of one type of loyalty over the other in terms of 'interdependence'. Here, dealer loyalty is the dependent variable in the first equation and the independent or explanatory factor in the second. The results are shown in Supplementary Table S2.

In like manner, we estimate a similar binomial probit model for brand loyalty; the results are detailed in Supplementary Table S3. Based on Wald's chi-square statistic and the likelihood-based test, the results show that all bivariate models are statistically significant and that the null correlation hypothesis is not rejected.

The two biprobit tables show the results of: (a) a model that considers the twelve independent variables of our conceptual model as explanatory variables for brand loyalty, plus dealer loyalty; and (b) a model that considers the eight independent variables of our conceptual model for dealer loyalty, plus brand loyalty.

This analysis led us to find that, in the first models, brand loyalty as an explanatory variable for dealer loyalty, shows a greater impact than dealer loyalty as an explanatory variable for brand loyalty (brand prevails over dealer). However, on further analysis, we see that in the last model where unassociated variables are discarded, the impact of dealer loyalty over brand loyalty is more considerable (dealer prevails over brand). In this context, both types of loyalties influence each other. On the other hand, the marginal effects of 3.4.1 and 3.4.2 (Supplementary Tables S2 and S3) led to an important result of the research. The producers considered loyal

Table 5. Chi-square test between both types of loyalty. ${ }^{1}$

\begin{tabular}{llllll}
\hline & & \multicolumn{2}{l}{ Loyalty to dealers } & \\
\cline { 3 - 5 } & & & Loyal & Disloyal & Total \\
\hline \multirow{2}{*}{ Loyalty to brands } & Loyal & Count and \% of total & $156(85.72)$ & $26(14.28)$ & 182 \\
& Disloyal & Count and \% of total & $143(37.43)$ & $239(62.57)$ & 382 \\
& & Total & 299 & 265 & 564 \\
\hline
\end{tabular}

${ }^{1}$ Pearson chi-square $=115.4$ and was significant at the 0.01 level. 
to dealers are $52.80 \%$ more likely to be loyal to brands, as opposed to producers who are disloyal to dealers. On the other hand, producers loyal to brands are $45.82 \%$ more likely to be loyal to dealers of agricultural equipment, as opposed to those who are brand disloyal.

Table 6 shows a summary of coefficients for brand loyalty and dealer loyalty that result from the different models. We can observe that all 'mean tests' indicate that, on average, the differences between the parameters are not statistically significant. This is a conclusive result that shows no relevant differences in the impact that one type of loyalty has over the other. This is, the decision to be loyal to the brand is linked to the decision to be loyal to the dealer, and vice-versa.

\section{Discussion}

This work analyzed how loyal agricultural producers are to brands and dealers of agricultural equipment in Argentina. Resorting to a combination of cluster analysis and probit models, we have been able to identify loyal and disloyal producers to brands and dealers, establish the explanatory variables affecting each type of loyalty, and the influence of brand loyalty on dealer loyalty and vice versa.

Regarding the question of how loyal Argentinian producers are to agricultural capital equipment brands and dealers, we found two significantly different groups, in terms of brand loyalty and dealer loyalty. The cluster analysis resulted in a new multi-criteria concept of loyalty, which reflects a blend of behavioral and attitudinal loyalty, and which we call 'empirical loyalty'. The results show that $32 \%$ of the producers can be considered 'empirically loyal' to brands, while $53 \%$ of them can be considered 'empirically loyal' to dealers.

In terms of factors that impact brand and dealer loyalty, we identified five explanatory variables for brand loyalty and four for dealer loyalty, including three new variables included in our model (cognitive styles, residence, and rented land). The explanatory variables for brand loyalty are inherent to the farmer's characteristics, behaviors, and attitudes. While dealer loyalty explanatory variables are mostly related to the farm and farmer's characteristics.

To the question of how brand loyalty and dealer loyalty are associated, and how do they influence each other, the results show the significant impact that brand loyalty and dealer loyalty have on each other. In the Argentinian agricultural equipment market, producers' loyalty to brands and dealers are closely related, and it is difficult to reflect on one without the other, in a reciprocal relationship.

Concerning how important is dealer financing for brand and dealer loyalty, our estimations show that this variable, although it is not independent of dealer loyalty, is not statistically significant. However, as managers in this industry explained in interviews, dealers must provide financing to its buyer and manage the business of the used machinery, which in this industry is very important to sell the new equipment. We also observe the variable capital equipment 'price', as well as the 'relationship of dealers with producers', are independent of brand and dealer loyalty. However, the variable 'performance' is a relevant variable to explain brand loyalty.

Table 6. Test for differences in means in the bivariate models. ${ }^{1}$

\begin{tabular}{lllllll}
\hline Model & DLOYALTY mean & BLOYALTY mean & diff. & Ho: diff. $=\mathbf{0}$ & \\
\cline { 5 - 7 } & & & Ha: diff. $<\mathbf{0}$ & Ha: diff. $>\mathbf{0}$ & $\begin{array}{l}\text { Ha: diff. }<\mathbf{0} \text { or } \\
\text { diff. }>\mathbf{0}\end{array}$ \\
\hline 3.1 & 1.7635 & 1.1557 & 0.6078 & $P=0.6960$ & $P=0.3040$ & $P=0.6081$ \\
3.2 & 1.5535 & 1.2518 & 0.3016 & $P=0.6179$ & $P=0.3821$ & $P=0.7642$ \\
3.3 & 1.5929 & 1.2168 & 0.3761 & $P=0.6912$ & $P=0.3088$ & $P=0.6176$ \\
3.4 & 1.8237 & 1.2984 & 0.5253 & $P=0.7825$ & $P=0.2175$ & $P=0.4350$ \\
\hline
\end{tabular}

${ }^{1}$ All contrasts performed at the 0.01 level of significance. 
We must add that the aftermarket parts and service can be critical to explain dealer loyalty. This is, how well the dealer manages the provision of services, spare parts, resale of used machinery, after-sales, etc. defines the retention of a customer. Consequently, the dealer plays a crucial role in what we refer to as the 'extended product'. Producers' dependence does not apply only to the 'narrow product' (the machinery itself), but also to the 'extended product' (after-sales services, spare parts, etc.).

Regarding the relation of the explanatory variables and brand loyalty, as we observe in Supplementary Table S4, that analytical agricultural producers are $8.88 \%$ more likely to be considered loyal to agricultural machinery brands than intuitive or balanced producers. Those who partially or strongly consider that there are differences between generic and trademark products are 19.59 and $13.18 \%$, respectively, more prone to be considered loyal than those who do not consider such differences. Producers who attach great importance to product performance are $13.89 \%$ more likely to be considered loyal to such brands, compared to those that give less value to this attribute. On the other hand, agricultural producers with a higher level of education are $9.50 \%$ less likely to be considered loyal to agricultural machinery brands. Older producers (more than 54 years old) are 16.80 and $28.50 \%$ less likely to be loyal to agricultural machinery brands, respectively, when compared to the younger farmers.

In terms of dealer loyalty, producers who rent at least $50 \%$ of the land where they carry out their agricultural operations are $14.87 \%$ more likely to be loyal to agricultural machinery dealers, compared to those who rent less than 50\%. Those with medium and high gross sales volumes have 13.40 and $11.07 \%$ more chances of loyalty than those with the lowest gross sales volumes. As a counterpart, older producers above 55 years old are 11.50 and $13.40 \%$ less likely to be loyal to distributors of agricultural machinery compared with the youngers, below 55 years, while the loyalty of those who reside farther from their farm is $11 \%$ less likely, compared to those who reside closer or even in the same farm.

All these estimates a relevant for the Argentine context, in the time frame in which we collected the information, the year 2017.

\section{Conclusions}

The contributions of this paper are three-fold: Firstly, the establishment and measurement of an 'empirical' definition of brand and dealer loyalty combining attitudinal and behavioral factors. Brand loyalty is a multidimensional concept consisting of a mix of both behavioral and attitudinal dimensions that benefits one firm relative to its competitors (Watson et al., 2015). In this study, we identified and characterized two significantly different groups, in terms of brand and dealer loyalty: 'empirically loyal' and 'empirically disloyal' producers.

Secondly, in this paper we have been able to identify and quantify the impact of the explanatory factors of brand and dealer loyalty. We must remark that the variables that influence brand and dealer loyalty are not the same, except for 'age', according to our estimations. The hallmark of our work is that we have been able to include in our conceptual model variables that are important to influence both types of loyalty: cognitive styles for brand loyalty, and percentage of rented land and producers' residence (distance from the farm) for dealer loyalty.

Thirdly, we extended previous work such as Harbor (2006), establishing a dual loyalty relationship between brand and dealer loyalty, and including new variables in the conceptual model. The results of Harbor's (2006) work, for US capital equipment, show that dealer loyalty directly affects brand loyalty, but the evidence is less statistically significant that brand loyalty can be a predictor of dealer loyalty. While in our work, regarding Argentine capital equipment, the results show that there is a mutual relationship: brand loyalty predicts dealer loyalty, and at the same time, dealer loyalty predicts brand loyalty. 
The first theoretical implication of this work is that our conceptual model can be taken as a starting point to develop further research that includes attitudinal and behavioral variables as possible influencers of 'loyalty' in the field of agribusiness. A second theoretical implication is that the explanatory factors of brand loyalty are all inherent to the producer, his 'beliefs and attitudes'. The last theoretical implication is that the explanatory variables of dealer loyalty combine a characteristic inherent to the producer (age) and three other business/farming factors, showing some sort of symbiosis between the characteristics of the producer and his firm (farm).

The management implications allow further understanding of the purchasing behavior of Argentinian producers. We identified three implications: working with dealers to develop brand recognition, understanding producers' purchasing behavior, and segmenting producers between loyal and non-loyal customers.

Agricultural capital equipment firms must concentrate and make efforts to have their dealers develop a brand image. There is a combination of the two loyalties (dual loyalty) in the purchasing process: brands and dealers need each other; none prevails in their attempts to attract customers.

A second implication is understanding the factors that drive agricultural producers to purchase new equipment. The producer is a professional business-oriented purchaser. As such, technical aspects are balanced with the business opportunity to make the best economic decision. However, also emotional aspects play an important role in the purchasing process, as does the bond and trust built based on some product characteristics and the service provided by the dealer.

The third implication relates to the importance of segmenting producers, identifying the loyal and the nonloyal producers. As our results show, agricultural producers' loyalty to brands and dealers is not equally intense. Recognizing loyal and non-loyal purchasers, identifying the factors that drive them to purchase agricultural equipment, and developing appropriate marketing strategies to attract different types of producers is an important task for marketing departments in agricultural equipment companies.

The limitations of this research are related to the fact that the data is based on a survey of producers from the Humid Pampas in Argentina (the main agricultural region in the country), and which does not include small producers (producers who operate less than 300 hectares), in a particular year (2017). This work could be extended to include data from multiple years, and further comparisons with results from other regions and countries. The relationship established in this paper between brand loyalty and cognitive styles may allow us to study these topics from a behavioral perspective.

\section{Supplementary material}

Supplementary material can be found online at https://doi.org/10.22434/IFAMR2021.0088

Table S1. Dependent and independent variable list.

Table S2. Seemingly unrelated bivariate probit models: first dealer loyalty as the dependent, and then brand loyalty as the dependent.

Table S3. Seemingly unrelated bivariate probit models: first brand loyalty as the dependent, and then dealer loyalty as the dependent.

Table S4. Univariate probit models for brand loyalty and dealer loyalty.

\section{References}

Ag Equipment Intelligence. 2018. Brand loyalty in the farm equipment business. Ag Equipment Intelligence, Brookfield, WI, USA. Available at: https://www.farm-equipment.com/ext/resources/aei/Reports/ AEI_Brand-Loyalty-in-the-Farm-Equipment-Business_Report_0418_email.pdf. 
Anisimova, T. and F. Mavondo. 2014. Aligning company and dealer perspectives in corporate branding: implications for dealer satisfaction and commitment. Journal of Business-to-Business Marketing 21(1): 35. https://doi.org/10.1080/1051712X.2014.857501

Bedano, J. and A. Domínguez. 2016. Large-scale agricultural management and soil meso- and macrofauna conservation in the Argentine Pampa. Sustainability 8(7): 653. https://doi.org/10.3390/su8070653

Bourdeau, B.L. 2005. A new examination of service loyalty: identification of the antecedents and outcomes of an attitudinal loyalty framework. Doctoral dissertation, The Florida State University College of Business, Tallahassee, FL, USA. Available at: https://diginole.lib.fsu.edu/islandora/object/fsu:181780/ datastream $/ \mathrm{PDF} / \mathrm{view}$

Brown, B., D. Bellenger and W. Johnston. 2007. The implications of business-to-business and consumer market differences for B2B branding strategy. Journal of Business Market Management 1: 209-230. https://doi.org/10.1007/s12087-007-0011-x

Cassia, F. and F. Magno. 2019. A framework to manage business-to-business branding strategies. EuroMed Journal of Business 14(2): 10-122. https://doi.org/10.1108/EMJB-08-2018-0047

Cassia, F., N. Cobelli and M. Ugolini. 2017. The effects of goods-related and service related B2B brand images on customer loyalty. Journal of Business \& Industrial Marketing 32(5): 722-732. https://doi. org/10.1108/JBIM-05-2016-0095

Dick, A. and K. Basu. 1994. Customer loyalty: toward an integrated conceptual framework. Journal of the Academy of Marketing Science 22(2): 99. https://doi.org/10.1177/0092070394222001

Elsäßer, M. and B. Wirtz. 2017. Rational and emotional factors of customer satisfaction and brand loyalty in a business-to-business setting. Journal of Business \& Industrial Marketing 32(1): 138. https:// doi.org/10.1108/JBIM-05-2015-0101

Fortes, V., G. Milan, L. Eberle and D. De Toni. 2019. Brand loyalty determinants in the context of a soft drink brand. Revista de Administração Mackenzie 20(5). https://doi.org/10.1590/1678-6971/eRAMR190015

Glynn, M.S. 2010. The moderating effect of brand strength in manufacturer-reseller relationships. Industrial Marketing Management 39(8): 1226-1233. https://doi.org/10.1016/j.indmarman.2010.02.019

Gujarati, D. 2003. Econometrics, $4^{\text {th }}$ edition. McGraw-Hill, New York, NY, USA.

Gupta, S., B. Schivinski and M. Brzozowska-Woś. 2017. Antecedents and consequences of brand loyalty. Handel Wewnętrzny 5(370): 200-212.

Harbor, A. 2006. Assessing agricultural input brand loyalty among United States mid-size and commercial producers. Doctoral dissertation, Purdue University, West Lafayette, IN, USA.

Harbor, A., M. Martin and J. Akridge. 2008. Assessing input brand loyalty among U.S. agricultural producers. International Food and Agribusiness Management Review 11(1): 17-34. https://doi.org/10.22004/ ag.econ.53626

Huber, F. and A. Herrmann. 2001. Achieving brand and dealer loyalty: the case of the automotive industry. The International Review of Retail, Distribution and Consumer Research 11(2): 97-122. https://doi. org/10.1080/713770584

Hutton, J.G. 1997. A study of brand equity in an organizational-buying context. Journal of Product \& Brand Management 6(6): 428-439. https://doi.org/10.1108/10610429710190478

Jones, T. and S. Taylor. 2007. The conceptual domain of service loyalty: how many dimensions? Journal of Services Marketing 21(1): 36-51. https://doi.org/10.1108/08876040710726284

Kool, M. 1994. Buying behavior of farmers. Doctoral dissertation, Wageningen UR, Wageningen, the Netherlands. Available at: https://edepot.wur.nl/132857

Kool, M., M. Meulenberg and D. Broens. 1997. Extensiveness of farmers' buying processes. Agribusiness 13(3): 301-318. https://doi.org/10.1002/(SICI)1520-6297(199705/06)13:3<301::AID-AGR5>3.0.CO;2-4

Korsakov, H., C. Alvarez and R. Lavado. 2015. Cover crops in the agricultural systems of the Argentine Pampas. Journal of Soil and Water Conservation 70(6): 134A-140A. https://doi.org/10.2489/jswc.70.6.134A

Kotler, P. 2000. Marketing management: the millennium edition. Person Prentice Hall, Upper Saddle River, NJ, USA.

Leek, S. and G. Christodoulides. 2012. A framework of brand value in B2B markets: the contributing role of functional and emotional components. Industrial Marketing Management 41(1): 106-114. https:// doi.org/10.1016/j.indmarman.2011.11.009 
Lilien, G.L. 2016. The B2B knowledge gap. International Journal of Research in Marketing 33(3): 543-556. https://doi.org/10.1016/j.ijresmar.2016.01.003

Maseshwari, V., G. Lodorfos and S. Jacobsen. 2014. Determinants of brand loyalty: a study of the experiencecommitment-loyalty constructs. International Journal of Business Administration 5(6): 13-23. https:// doi.org/10.5430/ijba.v5n6p13

Mohammadi, Z., P. Mac Clay, R. Feeney, P. Harmath, M. Keshavarz and M. Gunderson. 2020. Characterization of farmers' management practices and strategies: a comparison between Argentine and U.S. farmers. International Food and Agribusiness Management Review 23(2): 235-252. https://doi.org/10.22434/ IFAMR2019.0158

Möller, K. and M. Laaksonen. 1986. Situational dimensions and decision criteria in industrial buying: theoretical and empirical analysis. Advances of Business Marketing: a Research Annual 1: 163-207.

Montes de Oca, F., M. Tonello, J. Massaferro, M. Plastani and C. Laprida. 2020. The chironomids (Diptera: Chironomidae) of shallow lakes of the Humid Pampa Region, Argentina: an approach to paleoproductivity reconstruction. Palaios 35(4): 191-200. https://doi.org/10.2110/palo.2019.071

Mudambi, S. 2002. Branding importance in business-to-business markets: three buyer clusters. Industrial Marketing Management 31(6): 525-533. https://doi.org/10.1016/S0019-8501(02)00184-0

Narayandas, D. 2005. Building loyalty in business markets. Harvard Business Review 83(9): 131-139.

Nyström, A., J. Törnroos, N. Koporcic and M. Ivanova-Gongne. 2018. Summary: branding in the B2B context and future challenges. In: Koporcic, N., M. Ivanova-Gongne, A.G. Nyström and J.Å. Törnroos (ed.) Developing insights on branding in the B2B context. Emerald Publishing Limited, Bingley, UK, pp. 219-229. https://doi.org/10.1108/978-1-78756-275-220181013

Oliver, R. 1999. Whence consumer loyalty? Journal of Marketing, Fundamental Issues and Directions for Marketing 63: 33-44. https://doi.org/10.2307/1252099

Reportlinker. 2019. The global agriculture equipment market size is expected to reach USD 244.2 billion by 2025 , expanding at a CAGR of $8.9 \%$ from 2019 to 2025 . Available at: https://www.prnewswire. $\mathrm{com} /$ news-releases/the-global-agriculture-equipment-market-size-is-expected-to-reach-usd-244-2billion-by-2025--expanding-at-a-cagr-of-8-9-from-2019-to-2025--300794964.html

Rundle-Thiele, S. 2005. Elaborating customer loyalty: exploring loyalty to wine retailers. Journal of Retailing and Consumer Services 12(5): 333-344. https://doi:10.1016/j.jretconser.2004.11.002

Rundle-Thiele, S. and R. Bennett. 2001. A brand for all seasons? A discussion of brand loyalty approaches and their applicability for different markets. Journal of Product and Brand Management 10(1): 25-37.

Seyedghorban, Z., M. Matanda and P. LaPlaca. 2016. Advancing theory and knowledge in the business-tobusiness branding literature. Journal of Business Research 69(8): 2664-2677. https://doi.org/10.1016/j. jbusres.2015.11.002

Seyoum, S. 2018. Analysis of prevalence of Malaria and anemia using bivariate probit model. Annals of Data Science 5(2): 301-312. https://doi.org/10.1007/s40745-018-0138-3

Sokal, R. and C. Michener. 1958. A statistical method for evaluating systematic relationship. University of Kansas Scientific Bulletin 38: 1409-1438.

Steward, M., J. Narus, M. Roehm and W. Ritz. 2019. From transactions to journeys and beyond: the evolution of B2B buying process modeling. Industrial Marketing Management 83: 288-300. https://doi. org/10.1016/j.indmarman.2019.05.002

Tabaku, E. and M. Zerellari. 2015. Brand loyalty and loyalty programs: a literature review. Romanian Economic and Business Review 10(2): 71-86.

Viardot, E. 2017. Branding in B2B: the value of consumer goods brands in industrial markets. Journal of Business and Industrial Marketing 32(3): 337-346. https://doi.org/10.1108/JBIM-11-2014-0225

Walley, K., P. Custance, S. Taylor, A. Lindgreen and M. Hingley. 2007. The importance of brand in the industrial purchase decision: a case study of the UK tractor market. Journal of Business \& Industrial Marketing 2(6): 383-393. https://doi.org/10.1108/08858620710780145

Watson, G., J. Beck, C. Henderson and R. Palmatier. 2015. Building, measuring, and profiting from customer loyalty. Journal of the Academy of Marketing Science 43(6): 790-825. https://doi.org/10.1007/ s11747-015-0439-4 